\title{
Brazil, internal migration
}

\author{
Ernesto F. L. Amaral \\ Universidade Federal de Minas Gerais, Brazil \\ eflamaral@gmail.com
}

\begin{abstract}
Internal migration has been decisive in the process of rapid urbanization that has occurred throughout Brazil in recent decades. The usual explanation for this movement references poverty and the lack of job opportunities in the northeast combined with the concentration of industries in the southeast, mainly in the state of São Paulo. A process of spatial deconcentration has occurred since the 1970s. Internal migration is no longer predominantly a rural-to-urban phenomenon. Demographic growth has decreased in the Brazilian regions, due to diminishing fertility rates and changes in migration patterns. The new migration patterns are characterized by a relative decline in the number of people on the move. The decrease in population flows seems to indicate the disruption of networks between some locations. Current migrants tend to be more qualified than in the past; this characteristic contributes to decentralized development.
\end{abstract}

\section{Keywords}

Internal migration. Urbanization. Population growth. Development. Brazil.

\section{Final publication}

Amaral EFL. 2013. "Brazil: internal migration." In: The Encyclopedia of Global Human

Migration. (I Ness, ed.). Oxford: Wiley-Blackwell, 75: 1-7.

(http://doi.org/10.1002/9781444351071) 
Internal migration has been decisive in the process of rapid urbanization that has occurred throughout Brazil in recent decades. Between 1950 and 2000, Brazil's urban population grew from 36 percent to 81 percent of the total population (Table 1). During this period, the country underwent major transformations and became an industrial and urban, rather than an agricultural and rural, society. High levels of migration from the countryside to urban areas and agricultural frontiers occurred. Internal migration flows were heaviest in movements from the northeastern to the southeastern states. The usual explanation for this movement references poverty and the lack of job opportunities in the northeast combined with the concentration of industries in the southeast, mainly in the state of São Paulo. Migration from the northeast to the southeast was characterized by a rural-to-urban migration in the 1960s and 1970s.

Table 1. Distribution of the population by residential situation and region, Brazil, 19502010

\begin{tabular}{|c|c|c|c|c|c|c|c|}
\hline & 1950 & 1960 & 1970 & 1980 & 1991 & 2000 & 2010 \\
\hline $\begin{array}{l}\text { Residential } \\
\text { situation }\end{array}$ & $\%$ & $\%$ & $\%$ & $\%$ & $\%$ & $\%$ & $\%$ \\
\hline Urban & 36.16 & 45.08 & 55.98 & 67.70 & 75.47 & 81.23 & $*$ \\
\hline Rural & 63.84 & 54.92 & 44.02 & 32.30 & 24.53 & 18.77 & $*$ \\
\hline \multicolumn{8}{|l|}{ Region } \\
\hline North & 3.94 & 4.13 & 4.43 & 5.59 & 6.98 & 7.60 & 8.32 \\
\hline Northeast & 34.60 & 31.59 & 30.34 & 29.24 & 28.91 & 28.12 & 27.84 \\
\hline Southeast & 43.41 & 43.76 & 42.68 & 43.40 & 42.65 & 42.63 & 42.10 \\
\hline South & 15.09 & 16.75 & 17.65 & 16.00 & 15.05 & 14.79 & 14.37 \\
\hline Central West & 2.95 & 3.77 & 4.90 & 5.78 & 6.41 & 6.85 & 7.37 \\
\hline $\begin{array}{l}\text { Total } \\
\text { population }\end{array}$ & $51,944,397$ & $70,992,343$ & $94,508,583$ & $121,150,573$ & $146,917,459$ & $169,590,693$ & $190,632,694$ \\
\hline
\end{tabular}

Note: *These data were not yet available when this essay was completed.

Source: Brazilian Institute of Geography and Statistics (IBGE), 1950-2010 demographic censuses (http://seriesestatisticas.ibge.gov.br).

Lower-class people migrated, and still migrate, to the southeast because that area is Brazil's most industrialized region and has numerous job opportunities (Amaral 2008). Demand from major economic centers has caused population redistribution among the different states, agglomerating the majority of the population in urban clusters (Braga \& Rezende 2010). An important feature of this process is that areas with more employment opportunities are 
characterized by more modern industries (the southeast) and tend to attract the female population from less developed areas (the northeast). However, migration rates from the southeast to the northeast are higher for men than for women. Areas with fewer opportunities for women to enter the labor force attract more male migrants (Rogers \& Castro 1981; Amaral 2008).

A process of spatial deconcentration has occurred since the 1970s. Internal migration is no longer predominantly a rural-to-urban phenomenon (Baeninger 2000; Cunha \& Baeninger 2000; Brito et al. 2001; Amaral 2008; Braga \& Rezende 2010). Demographic growth has decreased in the Brazilian regions (Table 2), due to diminishing fertility rates and changes in migration patterns (Brito et al. 2001).

Table 2. Percentage population growth rates by residential situation and region, Brazil, 1950-2010

\begin{tabular}{l|cccccc}
\cline { 2 - 7 } & $1950-60$ & $1960-70$ & $1970-80$ & $1980-91$ & $1991-2000$ & $2000-10$ \\
\hline $\begin{array}{l}\text { Residential } \\
\text { situation }\end{array}$ & & & & & & \\
Urban & 5.15 & 5.22 & 4.44 & 2.97 & 2.47 & $*$ \\
Rural & 1.55 & 0.57 & -0.62 & -0.67 & -1.31 & $*$ \\
\hline Region & & & & & & \\
North & 3.34 & 3.47 & 3.70 & 3.85 & 2.86 & 2.09 \\
Northeast & 2.08 & 2.40 & 2.16 & 1.83 & 1.31 & 1.07 \\
Southeast & 4.07 & 3.45 & 2.48 & 1.38 & 1.43 & 0.87 \\
South & 3.06 & 2.67 & 2.00 & 1.77 & 1.62 & 1.05 \\
Central West & 5.36 & 5.60 & 4.05 & 3.01 & 2.39 & 1.90 \\
\hline Brazil & 2.99 & 2.89 & 2.48 & 1.93 & 1.64 & 1.17 \\
\hline
\end{tabular}

Note: *These data were not yet available when this essay was completed.

Source: Brazilian Institute of Geography and Statistics (IBGE), 1950-2010 demographic censuses (http://seriesestatisticas.ibge.gov.br).

Areas that had previously attracted large numbers of people (the central west and São Paulo) experienced a decrease in immigration rates in the 1980s (Cunha \& Baeninger 2000). Many migrants stopped leaving states that were previously characterized by high emigration rates (Minas Gerais and Paraná); migrants in those states instead moved to areas within their own states. Levels of migration from the northeast to the southeast remained high. However, large increases in immigration rates to the northeast also occurred. These increases featured a considerable return movement to the region. São Paulo's population declined, in contrast with the growth of other metropolitan areas in the country. The migratory flow to the southeast and 
toward the boundary regions (north and central west) decreased. Moreover, migratory losses in the northeast and south have fallen considerably (Table 3).

Table 3. Net migration by region, Brazil, 1960-2004

\begin{tabular}{l|cccccc}
\hline Region & $1960-70^{*}$ & $1970-80^{*}$ & $1986-91 * *$ & $1986-$ & $1995-$ & $1999-$ \\
\hline North & $-51,063$ & 585,397 & 131,218 & 131,323 & 78,584 & 63,741 \\
Northeast & $-1,754,761$ & $-2,402,244$ & $-876,534$ & $-876,545$ & $-788,146$ & $-164,139$ \\
Southeast & 815,884 & $2,262,364$ & 640,138 & 640,132 & 482,388 & $-215,308$ \\
South & 371,175 & $-1,613,377$ & $-185,391$ & $-185,369$ & $-19,172$ & 34,586 \\
Central West & 746,611 & 638,281 & 290,569 & 290,559 & 246,346 & 203,568 \\
\hline
\end{tabular}

Source: *Cunha \& Baeninger (2000), using information on place of previous residence (last-move data), based on 1970-1980 demographic censuses; **Cunha \& Baeninger (2000), using information on place of residence five years in the past, based on 1991 demographic census; ***Brito \& Carvalho (2006), using information on place of residence five years in the past, based on 1991-2000 demographic censuses and 2004 National Household Survey (PNAD).

With regard to the border areas (the central west and the north), the latest migration flows are directed to major municipalities in these regions. We cannot accurately create chronological differentiations between periods, as if one type of migration completely displaced another. It is important to differentiate among types of migration over time, but it is equally important to note that these types of migration occurred concomitantly at different times, and that one type is more visibly prevalent in a given period than in others (Amaral et al. 2002). The interaction between old and new trends in population flows establishes new patterns of internal migration in a country with a multiplicity of contexts (Braga \& Rezende 2010). Currently, flows are directed to different locations (suburbs of large cities, medium-sized cities, and migratory returns) simultaneously with the retention of old patterns (flows from the northeast to the southeast), due to the stability of social networks among migrants (Braga \& Rezende 2010; Lima \& Braga 2010).

In the early 21 st century, the most important flow is the urban-urban migration pattern. Two important aspects of this new pattern are the increasing significance of medium-sized cities and intra-metropolitan migration. Intra-metropolitan migration occurs between central urban areas and peripheral territories. The upper classes segregate themselves in gated communities separate from the lower classes. Low-income people are concentrated in run-down urban areas. Internal migration has become more complex, with a wide variety of places of origin and 
destination and a change in the socioeconomic characteristics of migrants (Roberts 1995; Baeninger 2000; Cunha \& Baeninger 2000; Cerrutti \& Bertoncello 2003).

The new migration patterns are characterized by a relative decline in the number of people on the move. The decrease in population flows seems to indicate the disruption of networks between some locations. This process affects the transmission of human capital between different areas, which is important for the development of the country. The cycle of rural exodus has also ended. This exodus was one cause of the overloading of public services and infrastructure, the growth of slums in urban centers, the rise of unemployment and informal labor, and the emptying of rural areas. Current migrants tend to be more qualified than in the past; this characteristic contributes to decentralized development (Braga \& Rezende 2010).

Scholars have often hypothesized that migration worked to ease the high fertility rates of Brazil's rural areas. It was an open question whether rural-to-urban migration would decrease as a response to the decline of rural fertility, a decline that became widespread during the 1980s. If the migratory balance, in conjunction with the decline in fertility, had persistently been negative for rural areas, uninhabited areas would have appeared. However, migratory movements appear to have adjusted themselves to the decline of fertility (see Table 3). Brazil's spatial distribution appears to be moving quickly toward stabilization. Although rural-to-urban migration has decreased in the last decades, officials continue to face the challenge of implementing public policies that prevent declining rural fertility and migratory movements from creating deserted areas.

Currently, the growth of large metropolitan areas has slowed, and flows have been redirected to medium and nonmetropolitan municipalities. In metropolitan areas, a trend toward concentrating the population in peripheral municipalities rather than in urban centers has emerged. Based on demographic and economic indicators, as well as on flows of goods and services, the municipalities of Belém, Belo Horizonte, Brasília, Campinas, Curitiba, Fortaleza, Goiânia, Porto Alegre, Recife, Rio de Janeiro, Salvador, and São Paulo and its surroundings are defined as metropolitan areas (Brito et al. 2001). Table 4 shows the distribution of Brazil's urban population in the context of municipality categories. With respect to nonmetropolitan areas, 
municipalities smaller than 20,000 people maintained about one-quarter of the population in 1970 and one-fifth in 1980.

Table 4. Percentage distribution of the urban population by municipality category, Brazil, 1970-2000

\begin{tabular}{l|cccc}
\hline Municipality category & 1970 & 1980 & 1991 & 2000 \\
\hline Nonmetropolitan areas & & & & \\
$<20,000$ inhabitants & 25.82 & 20.92 & 19.07 & 18.57 \\
$20,000-49,999$ & 9.48 & 9.91 & 11.29 & 10.60 \\
$50,000-99,999$ & 5.77 & 7.40 & 8.07 & 8.28 \\
$100,000-499,999$ & 10.29 & 14.84 & 16.41 & 17.31 \\
500,000 or more & 0.00 & 0.00 & 2.23 & 4.25 \\
Total & $\mathbf{5 1 . 3 6}$ & $\mathbf{5 3 . 0 7}$ & $\mathbf{5 7 . 0 7}$ & $\mathbf{5 9 . 0 2}$ \\
\hline Metropolitan areas & & & & \\
$<20,000$ inhabitants & 1.09 & 0.43 & 0.27 & 0.28 \\
20,000-49,999 & 2.56 & 1.49 & 1.15 & 0.87 \\
$50,000-99,999$ & 2.03 & 3.10 & 2.16 & 2.30 \\
100,000-499,999 & 7.47 & 6.62 & 8.02 & 8.78 \\
500,000 or more & 1.40 & 4.19 & 4.76 & 4.91 \\
Metropolitan center & 34.09 & 31.11 & 26.56 & 23.83 \\
Total & $\mathbf{4 8 . 6 4}$ & $\mathbf{4 6 . 9 3}$ & $\mathbf{4 2 . 9 3}$ & $\mathbf{4 0 . 9 8}$ \\
\hline
\end{tabular}

Source: Brito et al. (2001), based on 1970-2000 demographic censuses.

Over time, this proportion declined in favor of larger municipalities, particularly those with populations of between 100,000 and 500,000 inhabitants. As for metropolitan areas, nearly half of the urban population lived in these locations in 1970 and 1980, which represented the peak of urban concentration. In 1970, about 34 percent of the urban population lived in metropolitan centers. Since 1980, urban populations have spread out, leading to a reduction in the relative importance of the metropolitan centers. However, most of the population living in metropolitan areas is still found in municipalities with over 100,000 inhabitants. In 2000, nearly 92 percent of the population of metropolitan areas lived in these municipalities. Despite changes in migration patterns, 41 percent of the urban population resided in metropolitan areas in 2000, nearly 24 percent in metropolitan centers. That is, in 2000, around 33 million Brazilians lived in one of the 12 municipalities mentioned above.

We can detect population growth-rate patterns in those areas that state governments define as "metropolitan regions" (Table 5). Between 1970 and 1980, most of these regions 
experienced a decrease in their growth rates. Only Curitiba, in the south of Brazil, increased its population growth rate when we compare the period between 1960 and 1970 with the period between 1970 and 1980. The reduction was apparent at the time of the 1991 census. Furthermore, data from 2000 indicate that Porto Alegre, Recife, Rio de Janeiro, and São Paulo metropolitan regions all had growth rates below 2 percent.

Table 5. Population growth rates by metropolitan region, Brazil, 1960-2000

\begin{tabular}{l|cccc}
\hline Metropolitan region & $1960-70$ & $1970-80$ & $1980-91$ & $\begin{array}{c}1991- \\
2000\end{array}$ \\
\hline Belém & 4.85 & 4.30 & 2.70 & 2.82 \\
Belo Horizonte & 6.25 & 4.67 & 2.50 & 2.40 \\
Curitiba & 5.04 & 5.80 & 3.00 & 3.17 \\
Fortaleza & 4.87 & 4.30 & 3.40 & 2.43 \\
Porto Alegre & 4.19 & 3.84 & 2.60 & 1.70 \\
Recife & 3.93 & 2.73 & 1.90 & 1.50 \\
Rio de Janeiro & 3.62 & 2.45 & 1.00 & 1.15 \\
Salvador & 4.77 & 4.39 & 3.20 & 2.15 \\
São Paulo & 5.53 & 4.45 & 1.90 & 1.63 \\
\hline
\end{tabular}

Source: Brazilian Institute of Geography and Statistics (IBGE), 1960-2000 demographic censuses (http://seriesestatisticas.ibge.gov.br).

An interesting aspect of the migration streams is that of returning migration. Census data indicate that population flow rates from the southeast to the northeast have been increasing over the last few decades. São Paulo still plays a central role in attracting migrants from the northeastern region. At the same time, important returning flows from the southeast to the northeast have been increasing (Baeninger 2000; Amaral 2008). Migration is no longer solely explainable by labor determinants (Jannuzzi 2000). For instance, migration flows caused by returning migrants are more heavily populated by younger age groups, because returning migration involves entire families moving from one region to another.

Consequently, more children are involved than other age groups. For instance, the migration pattern from Paraná to Brazilian locations other than São Paulo between 1975 and 1980 reveals higher rates for the younger age group (10-14) and declining rates for people who are at least 20 years old (Schmertmann 1999). Thus, these different migration patterns are evidence that rates are not only attributable to work-related movements. Patterns of migration by age depend on the regions and time that analysts study, as well as on the reasons for migration. 
Migration from the northeastern region to the southeastern region is composed mainly of people in the age groups 15-19 and 30-34. This is a typical migration flow that involves people moving in search of job opportunities. In these flows, rates are higher for working-age individuals (Rogers \& Castro 1981). In the case of migration from the southeast to the northeast, the flow rates of younger people are much higher. This finding is consistent with the argument that this particular migration flow is related to the movements of families. Thus, we find that migratory movements involving those regions have different patterns; the data support the argument that the southeastern region has more job opportunities for persons of working age, and the northeastern region is more attractive to people migrating as families (Amaral 2008).

Daily commutes between municipalities still characterize metropolitan areas. A growing body of research addresses this pendulum movement of people commuting daily from their homes to their places of work or study. These population flows provide indicators that reveal urban dynamics and shed light on the integration of municipalities within metropolitan areas. The 2000 census indicated that a total of 7.4 million people worked or studied outside their residential municipality (IBGE 2003).

Finally, the Brazilian Institute of Geography and Statistics is currently implementing a new and important instrument for gathering demographic, economic, social, and health information on Brazil's population. The Continuous National Household Survey (PNAD Contínua) will replace the National Household Survey (PNAD) in the next few years. Among other areas of interest, this new instrument will increase the amount of data on, and our understanding of, internal migration in Brazil. 


\section{References and further reading}

Amaral, E. F. L. (2008) Improvements of techniques to estimate migration rates: an application with Brazilian censuses data. Population Review 47(2), 1-24.

Amaral, E. F. L, Nascimento, R. R., \& Bueno, M. G. (2002) Síntese da migração em Goiás e no Distrito Federal nas últimas décadas [Synthesis of migration in Goiás and in the federal district in the last decades]. Sociedade e Cultura 5, 127-136.

Baeninger, R. (2000) São Paulo no contexto dos movimentos migratórios interestaduais [São Paulo in the context of inter-state migratory movements]. In Hogan et al. (2000), pp. 127169.

Baeninger, R. (ed.) (2010) População e Cidades: Subsídios para o Planejamento e para as Políticas Sociais [Population and cities: subsidies for planning and social policies]. Campinas, Brazil: Population Studies Center (NEPO), University of Campinas (UNICAMP).

Braga, F. G. \& Rezende, D. F. A. (2010) Análise de redes sociais e as conexões territoriais da migração no Brasil: padrões estruturais da migração interna entre 1980 e 2000 [Analysis of social networks and the territorial connections of migration in Brazil: structural patterns of internal migration between 1980 and 2000]. Paper presented at the XVII Encontro Nacional de Estudos Populacionais [XVII Brazilian National Meeting of Population Studies], Caxambu, Brazil, Sept. 20 -24, 2010.

Brito, F. \& Carvalho, J. A. M. (2006) As migrações internas no Brasil: as novidades sugeridas pelos censos demográficos de 1991 e 2000 e pelas PNADs recentes [Internal migration in Brazil: news suggested by 1991-2000 demographic censuses and by recent national household surveys]. Paper presented at the XV Encontro Nacional de Estudos Populacionais [XV Brazilian National Meeting of Population Studies], Caxambu, Brazil, Sept. 18-22, 2006.

Brito, F., Horta, C. J. G., \& Amaral, E. F. L. (2001) The Brazilian recent urbanization and the urban conurbations. Paper presented at the XXIV General Population Conference of the International Union for the Scientific Study of Population, Salvador, Brazil, Aug. 18-24, 2001.

Cerrutti, M. \& Bertoncello, R. (2003) Urbanization and internal migration patterns in Latin America. Paper presented at the Conference on African Migration in Comparative Perspective, Johannesburg, South Africa, June 4 -7, 2003.

Cunha, J. M. P. (ed.) (2006) Novas Metrópoles Paulistas: População, Vulnerabilidade e Segregação [New metropolis in São Paulo: population, vulnerability and segregation]. Campinas, Brazil: Population Studies Center (NEPO), University of Campinas (UNICAMP).

Cunha, J. M. P. \& Baeninger, R. (2000) A migração nos estados brasileiros no período recente: principais tendências e mudanças [Migration in Brazilian states in the recent period: main tendencies and changes]. In Hogan et al. (2000), pp.17-57.

Golgher, A. B. (2008) As cidades e a classe criativa no Brasil: diferenças espaciais na distribuição de indivíduos qualificados nos municípios brasileiros [Cities and the creative class in Brazil: spatial differences in the distribution of qualified individuals in Brazilian municipalities]. Revista Brasileira de Estudos de População 25(1), 109-129.

Golgher, A. B. \& Marques, D. H. F. (2009) Diversidad socioeconómica regional de los flujos de migración interna en Brasil [Regional socioeconomic diversity of internal migration flows in Brazil]. Economía, Sociedad y Território 9(31), 681-721.

Golgher, A. B., Rosa, C. H., \& Araújo-Júnior, A. F. (2008) Determinants of migration in Brazil: regional polarization and poverty traps. Papeles de Población 56, 135-171. 
Hogan, D. J. (ed.) (2001) Population Change in Brazil: Contemporary Perspectives. Campinas, Brazil: Population Studies Center (NEPO), University of Campinas (UNICAMP).

Hogan, D. J., Cunha, J. M. P., Baeninger, R., \& Carmo, R. L. (eds.) (2000) Migração e Ambiente em São Paulo: Aspectos Relevantes da Dinâmica Recente [Migration and environment in São Paulo: relevant aspects of the recent dynamic]. Campinas, Brazil: Population Studies Center (NEPO), University of Campinas (UNICAMP).

IBGE (2003) Censo Demográfico 2000: Migração e Deslocamento, Resultados da Amostra [2000 Demographic census: migration and displacement, results from the sample]. Rio de Janeiro, Brazil: Brazilian Institute of Geography and Statistics (IBGE).

Jannuzzi, P. M. (2000) Tasas específicas por motivos y acompañantes de la migración: una contribución a la interpretación y al uso de modelos de patrones etarios de migración [Specific rates by reasons and followers of migration: a contribution to the interpretation and to the use of models of age patterns of migration]. Notas de Población 28(70), 33-85.

Lima, E. E. C. \& Braga, F. G. (2010) Da rotatividade migratória à baixa migração: uma tipologia dos padrões da mobilidade populacional no Brasil [From migratory turnover to low migration: one typology of population mobility patterns in Brazil]. Paper presented at the XVII Encontro Nacional de Estudos Populacionais [XVII Brazilian National Meeting of Population Studies], Caxambu, Brazil, Sept. 20-24, 2010.

Matos, R. E. S. (2005a) Periferias de grandes cidades e movimentos populacionais [Peripheries in big cities and population movements]. Cadernos Metrópole 13, 71-105.

Matos, R. E. S. (ed.) (2005b) Espacialidades em Rede: População, Urbanização e Migração no Brasil Contemporâneo [Spatiality in network: population, urbanization and migration in contemporary Brazil]. Belo Horizonte, Brazil: Editora Com Arte.

Matos, R. E. S. \& Soares, W. (eds.) (2009) Desigualdades, Redes e Espacialidades Emergentes no Brasil [Inequalities, networks and emerging spatiality in Brazil]. Rio de Janeiro, Brazil: Garamond.

Rigotti, J. I. R. (2006) Geografia dos fluxos populacionais segundo níveis de escolaridade dos migrantes [Geography of population flows by levels of schooling of migrants]. Estudos Avançados 20(57), 237-254.

Rigotti, J. I. R. (2010) Información de los censos demográficos del Brasil sobre migraciones internas: críticas y sugerencias para el analisis [Information of Brazilian demographic censuses about internal migrations: criticisms and suggestions for analysis]. Notas de Población 88, 219-244.

Roberts, B. (1995) The Making of Citizens. London: Edward Arnold.

Rogers, A. \& Castro, L. J. (1981) Model Migration Schedules. Laxenburg, Austria: International Institute for Applied Systems Analysis.

Schmertmann, C. P. (1999) Estimating multistate transition hazards from last-move data. Journal of the American Statistical Association 94(445), 53-63. 